Article

\title{
Dynamics of Fe, Mn, and Al Liberated from Contaminated Soil by Low-Molecular-Weight Organic Acids and Their Effects on the Release of Soil-Borne Trace Elements
}

\author{
Junhao Qin ${ }^{1,2}$, Osim Enya ${ }^{2}$ and Chuxia Lin ${ }^{2, *}$ \\ 1 Key Laboratory of Agro-Environment in the Tropics, Ministry of Agriculture, South China Agricultural \\ University, Guangzhou 510642, China; J_Qin@scau.edu.cn \\ 2 School of Environment and Life Sciences, University of Salford, Greater Manchester M5 4WT, UK; \\ o.enya@edu.salford.ac.uk \\ * Correspondence: C.Lin@salford.ac.uk; Tel.: +44-161-295-5356
}

Received: 31 October 2018; Accepted: 28 November 2018; Published: 1 December 2018

\begin{abstract}
A 15-day batch experiment was conducted to investigate the behaviours of $\mathrm{Fe}, \mathrm{Mn}$, and Al oxides upon attack by three common low-molecular-weight organic acids, and their effects on liberation of trace elements from a multi-contaminated soil. While the capacity of malic acid to mobilize soil-borne $\mathrm{Fe}, \mathrm{Mn}$, and $\mathrm{Al}$ was weaker compared to citric and oxalic acids, a similar trend was observed, showing that the concentration of dissolved $\mathrm{Fe}, \mathrm{Mn}$, and $\mathrm{Al}$ increased with increasing duration of the experiment. Marked increase in metal concentrations only took place after 5 or 7 days of the experiment. For the same organic acid treatment, $\mathrm{Fe}, \mathrm{Mn}$, and $\mathrm{Al}$ all showed a very similar temporal variation pattern. The concentration of dissolved $\mathrm{Fe}, \mathrm{Mn}$, and $\mathrm{Al}$ was markedly controlled by the total $\mathrm{Fe}, \mathrm{Mn}$, and $\mathrm{Al}$ contained in the soil, respectively. It appears that manganese oxides were more reactive to the organic acids, as compared to their Fe and $\mathrm{Al}$ counterparts. However, when multiple organic acids were present, the soil-borne $\mathrm{Fe}, \mathrm{Mn}$, and $\mathrm{Al}$ were mobilized rapidly within the first 5 or 7 days of the experiment and then tended to decrease. The formation of insoluble $\mathrm{Fe}, \mathrm{Mn}$, and $\mathrm{Al}$ organic complexes tended to be enhanced due to co-existence of multiple organic acids, resulting in the re-immobilization of the dissolved $\mathrm{Fe}, \mathrm{Mn}$, and $\mathrm{Al}$. The organic acid-driven dissolution of $\mathrm{Fe}, \mathrm{Mn}$, or $\mathrm{Al}$ had a major control on the mobilization of $\mathrm{As}, \mathrm{Cr}, \mathrm{Zn}, \mathrm{Ni}, \mathrm{Cu}$, and $\mathrm{Cd}$ that were bound to these oxides with a correlation coefficient being frequently greater than 0.9 for As, $\mathrm{Cr}, \mathrm{Zn}$, and $\mathrm{Ni}$.
\end{abstract}

Keywords: arsenic; heavy metals; metal oxides; citric acid; malic acid; oxalic acid

\section{Introduction}

Oxides of iron $(\mathrm{Fe})$, manganese $(\mathrm{Mn})$, and aluminium $(\mathrm{Al})$ are effective sorbents for trace elements [1,2]. Therefore, they play an important role as the sinks for potentially toxic heavy metals and metalloids in various environmental compartments such as soils, sediments, and aerosols, etc. [3-6]. In soils that are contaminated by potentially toxic elements, the presence of soil-borne $\mathrm{Fe}, \mathrm{Mn}$, and $\mathrm{Al}$ oxides immobilize pollutants entering soils from external sources, and consequently reduce their bioavailability. This represents a major chemical mechanism through which the toxic effects of trace elements entering a soil system can be attenuated [7]. However, upon changes in environmental conditions, the trace elements bound to these oxides can be released. Soil acidification is an important driver for dissolution of metal oxides [8-10]. For manganese and iron that have variable valence, a drop in redox potential could also destabilize Fe and Mn oxides [11,12]. 
In vegetated soils, low-molecular-weight organic acids (LMWOAs) contained in root exudates of plants play an important role in mobilizing trace elements bound to $\mathrm{Fe}, \mathrm{Mn}$, and $\mathrm{Al}$ oxides in rhizospheric soils [13-16]. While localized acidification in rhizospheric soils due to secretion of organic acids from plant roots and rhizobacteria solubilizes $\mathrm{Fe}, \mathrm{Mn}$, and $\mathrm{Al}$ oxides, complexation of $\mathrm{Fe}, \mathrm{Mn}$, and $\mathrm{Al}$ with organic ligands is likely to play a more important role in the dissolution of $\mathrm{Al}, \mathrm{Mn}$, and Fe oxides [3,17-19]. In addition, certain types of organic acids such as oxalic acid also have a strong capacity to cause reductive dissolution of iron oxides [20,21].

In soil systems, $\mathrm{Al}, \mathrm{Mn}$, and Fe oxides, together with other soil minerals, compete for available LMWOAs, resulting in consumption of free organic ligands, and acid neutralization, which causes the increase in solution $\mathrm{pH}[7,22]$. This could, in turn, lead to re-immobilization of the mobilized $\mathrm{Al}, \mathrm{Mn}$, and $\mathrm{Fe}[7,23]$, and consequently re-immobilization of the previously released trace elements in the soil solutions. So far, there have not been detailed investigations on (a) competitive dissolution among $\mathrm{Al}$, $\mathrm{Mn}$, and Fe oxides upon attack by LMWOAs, (b) temporal variation in LMWOAs-mobilized Al, Mn, and $\mathrm{Fe}$, and (c) effects of (b) on trace elements in soil solutions. The aim of this study was to close the above knowledge gaps.

\section{Materials and Methods}

\subsection{The Contaminated Soil Used for the Experiment}

The selected soil samples were collected from the Moston Brook closed landfill site in the Greater Manchester region, northwestern England. Information about the sampling site was documented in Mukwaturi and Lin [24]. After collection, the soil samples were oven-dried at $40{ }^{\circ} \mathrm{C}$ for two days in the laboratory and then ground with a mortar and a pestle to pass through a $2 \mathrm{~mm}$ stainless steel sieve. This is done to achieve a very fine and homogenous sample prior to analysis. Samples were later stored in an air-tight re-sealable laboratory polythene bags for further use.

Prior to the batch experiment, the soil was characterized and some major chemical characteristics of the soil samples are given in Table 1. The soils had a $\mathrm{pH}$ of 7.1 and an electrical conductivity (EC) value of $0.039 \mathrm{dS} / \mathrm{m}$. The concentrations of $\mathrm{Cd}, \mathrm{Cu}, \mathrm{Ni}, \mathrm{Pb}$, and $\mathrm{Zn}$ exceeded the guideline values for soils with plant uptake $[25,26]$.

Table 1. Major physical and chemical characteristics of the soil materials used in this study.

\begin{tabular}{|c|c|c|}
\hline Parameter & Experimental Soil & Guideline Value for Soil with Plant Uptake \\
\hline $\mathrm{pH}$ & 7.1 & - \\
\hline $\mathrm{EC}(\mathrm{dS} / \mathrm{m})$ & 0.039 & - \\
\hline Total As (mg/kg) & 29.6 & $43 *$ \\
\hline Total Al (mg/kg) & 21,013 & - \\
\hline Total Ca (mg/kg) & 32,166 & - \\
\hline Total Cd (mg/kg) & 6.19 & $1.8 *$ \\
\hline Total Cr (mg/kg) & 68.8 & 130 * \\
\hline Total Cu (mg/kg) & 2768 & $200 * *$ \\
\hline Total Fe (mg/kg) & 28,131 & - \\
\hline Total K (mg/kg) & 1859 & - \\
\hline Total Mn (mg/kg) & 3865 & - \\
\hline Total $\mathrm{Na}(\mathrm{mg} / \mathrm{kg})$ & 959 & - \\
\hline Total Ni (mg/kg) & 811 & $230 *$ \\
\hline Total $\mathrm{Pb}(\mathrm{mg} / \mathrm{kg})$ & 1498 & $450 *$ \\
\hline Total Zn (mg/kg) & 1276 & $450 * *$ \\
\hline
\end{tabular}




\subsection{Experimental Design}

Seven treatments were set to observe the release of $\mathrm{Fe}, \mathrm{Mn}$, and $\mathrm{Al}$, other trace elements in the presence of three selected organic acids (citric acid, oxalic acid, and malic acid) and their combinations, as shown in Table 2.

Table 2. Composition of extracting solutions for seven treatments.

\begin{tabular}{cccc}
\hline Treatment & $\mathbf{0 . 0 1}$ M Citric Acid & $\mathbf{0 . 0 1}$ M Oxalic Acid & $\mathbf{0 . 0 1}$ M Malic Acid \\
\hline T1 & Yes & Yes & \\
T2 & & & Yes \\
T3 & Yes & Yes & Yes \\
T4 & Yes & Yes & Yes \\
T5 & & Yes & Yes \\
T6 & Yes & & \\
T7
\end{tabular}

A batch experiment was conducted with $125 \mathrm{~mL}$ plastic bottles being used as batch reactors. In each bottle, $10 \mathrm{~g}$ of the soil were mixed with $100 \mathrm{~mL}$ of a relevant solution (refer to Table 2). The bottle with contents was shaken by hand for $1 \mathrm{~min}$. and then placed in a paper box at room temperature. Various physical and chemical parameters in the extracting solution were monitored during a period of 15 days. In-situ measurement of $\mathrm{pH}, \mathrm{EC}$, and Eh was made 1, 3, 5, 7, and 15 days after the commencement of the experiment. Solution samples were also collected for determination of $\mathrm{Fe}$, $\mathrm{Mn}, \mathrm{Al}$ and other trace elements after each in-situ measurement. Before each in-situ measurement and sampling operation, the bottle with contents was shaken by hand for $1 \mathrm{~min}$. and then allowed to stand for $1 \mathrm{~h}$. An aliquot of supernatant $(5 \mathrm{~mL})$ was taken from each bottle. The supernatant was centrifuged for $10 \mathrm{~min}$ at $3500 \mathrm{rpm}$ and then passed through a $0.45 \mu \mathrm{m}$ filter with polytetrafluoroethylene (PTFE) membrane prior to analysis.

\subsection{Analytical Methods}

For the initial soil characterization, $\mathrm{pH} / \mathrm{Eh}$, and $\mathrm{EC}$ of the soil samples were measured in a 1:5 (soil:water) extract using a calibrated Mettler Toledo $320 \mathrm{pH} /$ Eh meter and a Mettler Toledo EC meter (Leicester, UK), respectively. Total element concentration was determined using a Niton XL2 Gold Hand-held XRF Analyzer (Winchester, UK). The instrument was calibrated by firstly analysing the 73,308 standard reference materials prior to sample analysis. To ensure accuracy and reliability of the results obtained, all analyses were performed in duplicates and the analysis time was set at $240 \mathrm{~s}$. The $\mathrm{pH}$ and Eh in the solutions for the incubation experiment were measured using a Mettler Toledo $320 \mathrm{pH} / \mathrm{Eh}$ meter. The EC in the solutions for the incubation experiment was measured using a Mettler Toledo EC meter. Concentrations of $\mathrm{Al}, \mathrm{As}, \mathrm{Cd}, \mathrm{Cr}, \mathrm{Cu}, \mathrm{Fe}, \mathrm{Mn}, \mathrm{Ni}, \mathrm{Pb}$, and $\mathrm{Zn}$ in the filtrate were determined using a Varian 720 ES inductively coupled plasma optical emission spectrometer (ICP-OES, Palo Alto, CA, USA).

\subsection{QA/QC and Statistical Analysis}

All the chemicals used in the experiment are of analytical grade. The experiments were performed in triplicate (i.e., each of the 7 treatments in the experiment was independently repeated three times). Repeatability analysis shows that the mean RSD for $\mathrm{pH}, \mathrm{Eh}, \mathrm{EC}, \mathrm{Al}, \mathrm{As}, \mathrm{Cd}, \mathrm{Cr}, \mathrm{Cu}, \mathrm{Fe}, \mathrm{Mn}, \mathrm{Ni}$, $\mathrm{Pb}$, and $\mathrm{Zn}$ was $<2.80 \%,<0.75 \%,<2.82 \%,<10.6 \%,<12.1 \%,<15.3 \%,<10.5 \%,<8.00 \%,<10.2 \%,<10.3 \%$, $<8.39 \%,<12.8 \%$, and $<4.96 \%$, respectively. Statistical analysis of the experimental data was performed using one-way analysis of variance (ANOVA) and the means compared using significant difference (Duncan) method at 5\% level (IBM SPSS software Version 17.0). "Descriptive statistics" followed by "explore" were used to test the data for normality. The "sig" value of Shapiro-Wilk is greater than 0.05 . The data in this study is consistent with the test of variance homogeneity using Levene 
statistic. All experimental data were presented as mean \pm standard error $(n=3)$. Pearson coefficient of correlation was used to determine the relationship between $\mathrm{Al}, \mathrm{Mn}$, or Fe and each of the trace elements investigated in this study.

\section{Results}

\subsection{Temporal Variation in $\mathrm{pH}$, Eh, and EC during the Period of the Experiment}

There was a consistent trend showing that $\mathrm{pH}$ in the soil solution increased over time during the 15-day incubation experiment. In comparison, the single organic acid treatments (T1-T3) tended to have higher $\mathrm{pH}$ compared to the combined organic acid treatments (T4-T7), and the combination of the three organic acid treatment (T7) had the lowest $\mathrm{pH}$ on any measurement events among all the 7 treatments (Table 3).

Table 3. Variation in $\mathrm{pH}$, Eh, and EC in the extracting solutions during the period of the experiment.

\begin{tabular}{|c|c|c|c|c|c|}
\hline Treatments & $1 \mathrm{~d}$ & $3 \mathrm{~d}$ & $5 \mathrm{~d}$ & $7 \mathrm{~d}$ & $15 \mathrm{~d}$ \\
\hline \multicolumn{6}{|l|}{$\mathrm{pH}$} \\
\hline $\mathrm{T} 1$ & $3.63 \pm 0.03 \mathrm{bE}$ & $4.11 \pm 0.02 \mathrm{cD}$ & $4.44 \pm 0.02 \mathrm{cC}$ & $5.38 \pm 0.10 \mathrm{bB}$ & $6.83 \pm 0.08 \mathrm{aA}$ \\
\hline $\mathrm{T} 2$ & $3.34 \pm 0.06 \mathrm{cE}$ & $4.78 \pm 0.01 \mathrm{aD}$ & $5.18 \pm 0.01 \mathrm{aC}$ & $5.88 \pm 0.02 \mathrm{aB}$ & $6.70 \pm 0.10 \mathrm{aA}$ \\
\hline T3 & $3.88 \pm 0.03 \mathrm{aE}$ & $4.50 \pm 0.03 \mathrm{bD}$ & $5.04 \pm 0.04 \mathrm{bC}$ & $6.01 \pm 0.02 \mathrm{aB}$ & $6.76 \pm 0.08 \mathrm{aA}$ \\
\hline $\mathrm{T} 4$ & $2.86 \pm 0.02 \mathrm{eE}$ & $3.36 \pm 0.01 \mathrm{eD}$ & $3.58 \pm 0.01 \mathrm{eC}$ & $4.29 \pm 0.02 \mathrm{~dB}$ & $5.27 \pm 0.12 \mathrm{cA}$ \\
\hline T5 & $3.33 \pm 0.03 \mathrm{cE}$ & $3.77 \pm 0.02 \mathrm{dD}$ & $4.06 \pm 0.02 \mathrm{dC}$ & $4.81 \pm 0.03 \mathrm{cB}$ & $5.66 \pm 0.06 \mathrm{bA}$ \\
\hline T6 & $2.99 \pm 0.04 \mathrm{dE}$ & $3.71 \pm 0.05 \mathrm{dD}$ & $4.07 \pm 0.04 \mathrm{dC}$ & $4.83 \pm 0.06 \mathrm{cB}$ & $5.87 \pm 0.02 \mathrm{bA}$ \\
\hline $\mathrm{T} 7$ & $2.73 \pm 0.01 \mathrm{fE}$ & $3.26 \pm 0.00 \mathrm{fD}$ & $3.50 \pm 0.00 \mathrm{fC}$ & $4.22 \pm 0.04 \mathrm{~dB}$ & $4.86 \pm 0.07 \mathrm{dA}$ \\
\hline \multicolumn{6}{|l|}{ Eh $(\mathrm{mV})$} \\
\hline $\mathrm{T} 1$ & $170 \pm 1.70 \mathrm{eA}$ & $149 \pm 0.88 \mathrm{~dB}$ & $128 \pm 0.96 \mathrm{dC}$ & $98.1 \pm 4.57 \mathrm{cD}$ & $-18.8 \pm 3.33 \mathrm{fE}$ \\
\hline $\mathrm{T} 2$ & $186 \pm 3.06 \mathrm{dA}$ & $112 \pm 0.81 \mathrm{fB}$ & $86.4 \pm 0.61 \mathrm{fC}$ & $67.5 \pm 1.31 \mathrm{dD}$ & $-7.23 \pm 2.02 \mathrm{eE}$ \\
\hline T3 & $156 \pm 1.91 \mathrm{fA}$ & $127 \pm 1.87 \mathrm{eB}$ & $93.9 \pm 2.29 \mathrm{eC}$ & $59.4 \pm 1.55 \mathrm{eD}$ & $-19.2 \pm 1.03 \mathrm{fE}$ \\
\hline $\mathrm{T} 4$ & $213 \pm 1.41 \mathrm{bA}$ & $192 \pm 0.64 \mathrm{bB}$ & $175 \pm 0.38 \mathrm{bC}$ & $160 \pm 1.10 \mathrm{aD}$ & $60.6 \pm 6.05 \mathrm{bE}$ \\
\hline T5 & $187 \pm 1.43 \mathrm{dA}$ & $169 \pm 1.17 \mathrm{cB}$ & $149 \pm 0.95 c C$ & $130 \pm 0.07 \mathrm{bD}$ & $40.1 \pm 3.07 \mathrm{cE}$ \\
\hline T6 & $205 \pm 2.41 \mathrm{cA}$ & $172 \pm 2.69 \mathrm{cB}$ & $147 \pm 2.37 \mathrm{cC}$ & $128 \pm 3.31 \mathrm{bD}$ & $29.7 \pm 1.02 \mathrm{dE}$ \\
\hline $\mathrm{T} 7$ & $220 \pm 0.61 \mathrm{aA}$ & $197 \pm 0.19 \mathrm{aB}$ & $180 \pm 0.12 \mathrm{aC}$ & $164 \pm 2.31 \mathrm{aD}$ & $81.3 \pm 3.44 \mathrm{aE}$ \\
\hline \multicolumn{6}{|l|}{$\mathrm{EC}(\mu \mathrm{S} / \mathrm{cm})$} \\
\hline $\mathrm{T} 1$ & $1374 \pm 43.4 \mathrm{cA}$ & $1016 \pm 2.85 \mathrm{~dB}$ & $1385 \pm 24.0 \mathrm{bA}$ & $874 \pm 7.00 \mathrm{cC}$ & $25.6 \pm 0.21 \mathrm{cD}$ \\
\hline $\mathrm{T} 2$ & $839 \pm 17.7 \mathrm{eA}$ & $311 \pm 2.03 \mathrm{gC}$ & $360 \pm 4.04 \mathrm{eB}$ & $196 \pm 3.70 \mathrm{dD}$ & $6.83 \pm 0.09 \mathrm{eE}$ \\
\hline T3 & $1319 \pm 15.6 \mathrm{cA}$ & $977 \pm 7.75 \mathrm{eB}$ & $1390 \pm 7.88 \mathrm{bA}$ & $867 \pm 3.61 \mathrm{cC}$ & $25.8 \pm 0.72 \mathrm{cD}$ \\
\hline $\mathrm{T} 4$ & $1820 \pm 26.6 \mathrm{aA}$ & $1132 \pm 0.88 c C$ & $1528 \pm 4.00 \mathrm{aB}$ & $921 \pm 3.18 b c D$ & $25.5 \pm 0.43 \mathrm{cE}$ \\
\hline $\mathrm{T} 5$ & $1375 \pm 48.2 \mathrm{cC}$ & $1590 \pm 7.86 \mathrm{aA}$ & $1406 \pm 12.9 \mathrm{bB}$ & $1093 \pm 169 \mathrm{bD}$ & $41.2 \pm 0.37 \mathrm{aE}$ \\
\hline T6 & $985 \pm 17.8 \mathrm{dA}$ & $941 \pm 3.28 \mathrm{fB}$ & $785 \pm 2.96 \mathrm{dC}$ & $739 \pm 11.1 \mathrm{cD}$ & $18.6 \pm 0.33 \mathrm{dE}$ \\
\hline $\mathrm{T} 7$ & $1517 \pm 1.53 \mathrm{bA}$ & $1526 \pm 2.65 \mathrm{bA}$ & $1336 \pm 5.49 \mathrm{cB}$ & $1330 \pm 4.67 \mathrm{aB}$ & $37.9 \pm 0.18 \mathrm{bC}$ \\
\hline
\end{tabular}

All values are presented as mean \pm standard error $(n=3)$. Means with different lower-case letters in the same column for each parameter are significantly different at $p<0.05$. Means with different capital letters in the same row are significantly different at $p<0.05$.

In contrast, the solution Eh tended to decrease with increasing duration during the incubation experiment. The single organic acid treatments (T1-T3) tended to have lower Eh, as compared to the combined organic acid treatments (T4-T7). The combination of the three organic acid treatment (T7) had the highest Eh on any measurement events among all the 7 treatments (Table 3).

There were different temporal variation patterns for EC among the 7 treatments in the earlier part (until the 7th day) of the experiment. Except for T2 and T6 that showed a continuously decreasing trend over time, EC in the treatments fluctuated markedly until the 7th day and then all the treatments exhibited a consistently decreasing trend toward the end of the experiment with the EC value becoming very low (Table 3). 


\subsection{Temporal Variation in Solution-borne $A l, F e$, and $M n$ During the Period of the Experiment}

For the single acid treatments (T1-T3), the solution-borne $\mathrm{Al}$ in $\mathrm{T} 1$ (citric acid treatment) and $\mathrm{T} 3$ (malic acid treatment) showed the same trend to increase with increasing incubation time though the value was lower in $\mathrm{T} 3$ than in $\mathrm{T} 1$ during the first 5 days. Unlike $\mathrm{T} 1$ and $\mathrm{T} 3$, the solution-borne $\mathrm{Al}$ in $\mathrm{T} 2$ (oxalic acid treatment) showed a gently decreasing trend until the 5th day and then sharply increased to the 7th day; after this, the concentration of $\mathrm{Al}$ in the solution slightly decreased to the end of the experiment (Table 4).

Table 4. Variation in $\mathrm{Al}, \mathrm{Fe}$, and $\mathrm{Mn}(\mathrm{mg} / \mathrm{L})$ in the extracting solutions during the period of experiment.

\begin{tabular}{|c|c|c|c|c|c|}
\hline Treatment & $1 \mathrm{~d}$ & $3 \mathrm{~d}$ & $5 \mathrm{~d}$ & $7 \mathrm{~d}$ & $15 \mathrm{~d}$ \\
\hline \multicolumn{6}{|l|}{ Al } \\
\hline $\mathrm{T} 1$ & $347 \pm 14.8 \mathrm{cD}$ & $533 \pm 7.06 \mathrm{eC}$ & $648 \pm 6.64 \mathrm{~dB}$ & $744 \pm 19.6 \mathrm{~dB}$ & $1632 \pm 27.7 \mathrm{aA}$ \\
\hline $\mathrm{T} 2$ & $368 \pm 7.52 \mathrm{cC}$ & $348 \pm 4.69 \mathrm{fD}$ & $273 \pm 7.55 \mathrm{fE}$ & $1279 \pm 14.3 \mathrm{bA}$ & $1144 \pm 10.5 \mathrm{cAB}$ \\
\hline T3 & $156 \pm 9.59 \mathrm{dE}$ & $261 \pm 6.04 \mathrm{gD}$ & $322 \pm 2.16 \mathrm{eC}$ & $794 \pm 2.99 \mathrm{~dB}$ & $1436 \pm 3.93 \mathrm{bA}$ \\
\hline $\mathrm{T} 4$ & $634 \pm 25.9 \mathrm{aC}$ & $929 \pm 11.3 \mathrm{bAB}$ & $1048 \pm 12.2 \mathrm{bA}$ & $1157 \pm 20.8 \mathrm{cA}$ & $631 \pm 20.4 \mathrm{fC}$ \\
\hline T5 & $494 \pm 14.1 \mathrm{bC}$ & $751 \pm 8.26 \mathrm{cB}$ & $885 \pm 5.99 \mathrm{cA}$ & $337 \pm 4.10 \mathrm{eD}$ & $688 \pm 13.0 \mathrm{eB}$ \\
\hline T6 & $480 \pm 21.7 \mathrm{bC}$ & $624 \pm 16.7 \mathrm{~dB}$ & $662 \pm 22.3 \mathrm{~dB}$ & $1135 \pm 21.0 \mathrm{cA}$ & $312 \pm 8.78 \mathrm{gD}$ \\
\hline $\mathrm{T} 7$ & $674 \pm 3.10 \mathrm{aE}$ & $1055 \pm 15.9 \mathrm{aC}$ & $1237 \pm 10.5 \mathrm{aB}$ & $1603 \pm 20.4 \mathrm{aA}$ & $791 \pm 23.7 \mathrm{dD}$ \\
\hline \multicolumn{6}{|l|}{$\mathrm{Fe}$} \\
\hline $\mathrm{T} 1$ & $287 \pm 10.9 \mathrm{eE}$ & $527 \pm 3.63 \mathrm{dD}$ & $714 \pm 10.9 \mathrm{dC}$ & $1066 \pm 28.2 \mathrm{~dB}$ & $2583 \pm 40.9 \mathrm{aA}$ \\
\hline $\mathrm{T} 2$ & $339 \pm 4.11 \mathrm{dC}$ & $190 \pm 7.80 \mathrm{eD}$ & $94.4 \pm 3.18 \mathrm{gE}$ & $1487 \pm 11.5 \mathrm{cB}$ & $2340 \pm 33.2 \mathrm{bA}$ \\
\hline $\mathrm{T} 3$ & $105 \pm 6.19 \mathrm{fE}$ & $208 \pm 5.20 \mathrm{eD}$ & $328 \pm 31.2 \mathrm{fC}$ & $682 \pm 5.85 \mathrm{eB}$ & $1674 \pm 23.3 \mathrm{cA}$ \\
\hline $\mathrm{T} 4$ & $639 \pm 22.3 \mathrm{bD}$ & $982 \pm 23.2 \mathrm{bC}$ & $1132 \pm 14.7 \mathrm{bB}$ & $1556 \pm 17.0 \mathrm{bA}$ & $1170 \pm 17.3 \mathrm{~dB}$ \\
\hline $\mathrm{T} 5$ & $406 \pm 5.77 \mathrm{cD}$ & $757 \pm 54.9 \mathrm{c} A B$ & $883 \pm 8.77 \mathrm{cA}$ & $364 \pm 38.6 \mathrm{fD}$ & $589 \pm 19.5 \mathrm{eC}$ \\
\hline T6 & $414 \pm 9.97$ cB & $522 \pm 17.4 \mathrm{dA}$ & $568 \pm 18.2 \mathrm{eA}$ & $400 \pm 0.03 \mathrm{fBC}$ & $381 \pm 16.7 \mathrm{fC}$ \\
\hline $\mathrm{T} 7$ & $707 \pm 15.9 \mathrm{aD}$ & $1100 \pm 2.77 \mathrm{aC}$ & $1346 \pm 6.66 \mathrm{aB}$ & $1967 \pm 18.2 \mathrm{aA}$ & $1142 \pm 6.54 \mathrm{dC}$ \\
\hline \multicolumn{6}{|l|}{ Mn } \\
\hline $\mathrm{T} 1$ & $183 \pm 10.9 \mathrm{eD}$ & $323 \pm 7.24 \mathrm{dC}$ & $416 \pm 7.44 \mathrm{~dB}$ & $472 \pm 30.1 \mathrm{cB}$ & $1054 \pm 11.9 \mathrm{aA}$ \\
\hline $\mathrm{T} 2$ & $158 \pm 0.20 \mathrm{eC}$ & $125 \pm 1.70 \mathrm{fCD}$ & $83.7 \pm 2.95 \mathrm{gE}$ & $616 \pm 42.4 \mathrm{bB}$ & $885 \pm 5.87 \mathrm{bA}$ \\
\hline T3 & $80.6 \pm 3.35 \mathrm{fE}$ & $144 \pm 3.22 \mathrm{eD}$ & $225 \pm 2.60 \mathrm{fC}$ & $491 \pm 32.1 \mathrm{cB}$ & $746 \pm 16.6 \mathrm{cA}$ \\
\hline $\mathrm{T} 4$ & $325 \pm 13.2 \mathrm{bD}$ & $507 \pm 8.45 \mathrm{bBC}$ & $543 \pm 4.66 \mathrm{cB}$ & $700 \pm 19.9 \mathrm{bA}$ & $73.8 \pm 4.84 \mathrm{fE}$ \\
\hline $\mathrm{T} 5$ & $288 \pm 9.84 \mathrm{cD}$ & $501 \pm 4.04 \mathrm{bB}$ & $563 \pm 4.01 \mathrm{bA}$ & $341 \pm 39.9 \mathrm{dCD}$ & $372 \pm 9.07 \mathrm{eC}$ \\
\hline T6 & $244 \pm 9.73 \mathrm{dC}$ & $354 \pm 6.28 \mathrm{cB}$ & $359 \pm 6.76 \mathrm{eB}$ & $96.8 \pm 6.86 \mathrm{eD}$ & $369 \pm 7.05 \mathrm{eA}$ \\
\hline $\mathrm{T} 7$ & $370 \pm 1.02 \mathrm{aD}$ & $641 \pm 6.14 \mathrm{aC}$ & $702 \pm 6.34 \mathrm{aB}$ & $954 \pm 6.81 \mathrm{aA}$ & $688 \pm 3.24 \mathrm{~dB}$ \\
\hline
\end{tabular}

All values are presented as mean \pm standard error $(n=3)$. Means with different lower-case letters in the same column for each parameter are significantly different at $p<0.05$. Means with different capital letters in the same row are significantly different at $p<0.05$.

For the combined two acid treatments (T4-T6), T4 (citric acid-oxalic acid treatment) and T6 (oxalic acid-malic acid treatment) showed a similar trend where solution-borne $\mathrm{Al}$ increased from the 1st day to the 7th day and then decreased to the end of the experiment. However, T5 (citric acid-malic acid treatment) exhibited a different temporal variation trend, showing that solution-borne $\mathrm{Al}$ increased from the 1st day to the 5th day and then increased to the 7th day, followed by a re-increase to the end of the experiment (Table 4).

For the combined three acid treatment (T7), there was a clear trend that solution-borne Al increased from the 1st day to the 7th day and then decreased to the end of the experiment with a value being very close for the 1st and the 15th day (the end of the experiment) (Table 4).

Similar to Al, the solution-borne Fe showed a consistent trend to increase over time for T1-T3. However, unlike $\mathrm{Fe}$, the concentration of solution-borne Fe was consistently in T1 than in T3 during the period of incubation experiment. The temporal variation pattern for solution-borne Fe was also very similar to that for solution-borne $\mathrm{Al}$ (Table 4). 
The temporal variation pattern in solution-borne Fe in T4-T6 was also very similar to that in solution-borne $\mathrm{Al}$ in $\mathrm{T} 4$ and $\mathrm{T} 6$, respectively. However, there was no marked variation in solution-borne Fe for T5, which is different from the solution-borne $\mathrm{Al}$ in $\mathrm{T} 5$ that had a strong peak on the 7th day of the experiment (Table 4). There was a high level of similarity in solution-borne Fe and solution-borne Al for T7 (Table 4).

In general, the temporal variation in solution-borne Mn showed a similar pattern to that of solution-borne Al for T1-T3 (Table 4). However, for the combined two acid treatments (T4-T6), the temporal variation in solution-borne Mn was more similar to that of solution-borne Fe but the peaks on the 5th day were much more evident, as compared to the latter (Table 4). For T7, the temporal variation pattern in solution-borne $\mathrm{Mn}$ was highly consistent with that for either $\mathrm{Al}$ or Fe (Table 4).

\subsection{Relationships Among Solution-Borne Al, Fe, and Mn at Different Sampling Times}

There was a close relationship among the solution-borne $\mathrm{Fe}, \mathrm{Mn}$, and $\mathrm{Al}$ (significant at $p<0.01$ ) for any of the sampling occasions during the period of the experiment. However, there was a tendency showing that the correlation coefficient between the two elements decreased over time. The lowest correlation coefficient $(r=0.576)$ was for the pair of solution-borne Al vs. solution-borne $\mathrm{Mn}$ on the 7th day of the experiment (Table 5).

Table 5. Correlation coefficient among Fe, Mn, and $\mathrm{Al}$ in the solution samples $(n=7)$.

\begin{tabular}{|c|c|c|c|c|}
\hline Time & Element & Al & $\mathrm{Fe}$ & Mn \\
\hline \multirow[t]{3}{*}{$1 \mathrm{~d}$} & $\mathrm{Al}$ & 1 & & \\
\hline & $\mathrm{Fe}$ & $0.982 * *$ & 1 & \\
\hline & Mn & $0.982^{* *}$ & $0.953^{* *}$ & 1 \\
\hline \multirow[t]{3}{*}{$3 d$} & $\mathrm{Al}$ & 1 & & \\
\hline & $\mathrm{Fe}$ & $0.984^{* *}$ & 1 & \\
\hline & $\mathrm{Mn}$ & $0.977^{* *}$ & $0.976^{* *}$ & 1 \\
\hline \multirow[t]{3}{*}{$5 d$} & $\mathrm{Al}$ & 1 & & \\
\hline & $\mathrm{Fe}$ & $0.985^{* *}$ & 1 & \\
\hline & Mn & $0.970 * *$ & $0.978^{* *}$ & 1 \\
\hline \multirow[t]{3}{*}{$7 \mathrm{~d}$} & $\mathrm{Al}$ & 1 & & \\
\hline & $\mathrm{Fe}$ & 0.770 ** & 1 & \\
\hline & Mn & $0.576^{* *}$ & $0.915^{* *}$ & 1 \\
\hline \multirow[t]{3}{*}{$15 \mathrm{~d}$} & $\mathrm{Al}$ & 1 & & \\
\hline & $\mathrm{Fe}$ & $0.885^{* *}$ & 1 & \\
\hline & $\mathrm{Mn}$ & $0.822 * *$ & $0.797^{* *}$ & 1 \\
\hline
\end{tabular}

\subsection{Relationship between $\mathrm{Fe}, \mathrm{Mn}$, or Al and Various Potentially Toxic Elements in the Solutions}

From Table 4, it can be seen that there was a close relationship between the solution-borne As and any of the solution-borne $\mathrm{Fe}, \mathrm{Mn}$, and $\mathrm{Al}$ though there was a trend showing that the correlation coefficient increased from the 1st day to the 5th day and then decreased to the end of the experiment (the 15th day).

For solution $\mathrm{Cd}$, a closer relationship with the solution-borne $\mathrm{Al}, \mathrm{Fe}$, or Mn was only observed in the sampling occasion before the earlier part of the experiment (the first 5 days). No significant relationships were observed on the 7th and the 15th days of the experiment. The solution-borne $\mathrm{Mn}$ tended to be more closely related to the solution-borne $\mathrm{Cd}$, as compared to the solution-borne $\mathrm{Al}$ and $\mathrm{Fe}$, which also showed no significant relationship with the solution-borne $\mathrm{Cd}$ on the first day of the experiment (Table 6). 
Table 6. Correlation coefficient between each selected trace metal and each of other elements investigated in this study $(n=7)$.

\begin{tabular}{ccccccccc}
\hline Time & Element & As & Cd & Cr & Cu & Pb & Zn & Ni \\
\hline \multirow{2}{1}{$1 \mathrm{~d}$} & $\mathrm{Al}$ & $0.907^{* *}$ & 0.397 & $0.954^{* *}$ & $0.964^{* *}$ & 0.077 & $0.979^{* *}$ & $0.972^{* *}$ \\
& $\mathrm{Fe}$ & $0.941^{* *}$ & 0.351 & $0.929^{* *}$ & $0.923^{* *}$ & -0.026 & $0.944^{* *}$ & $0.943^{* *}$ \\
& $\mathrm{Mn}$ & $0.841^{* *}$ & $0.552^{* *}$ & $0.980^{* *}$ & $0.934^{* *}$ & 0.227 & $0.998^{* *}$ & $0.987^{* *}$ \\
\hline \multirow{2}{*}{$3 \mathrm{~d}$} & $\mathrm{Al}$ & $0.986^{* *}$ & $0.744^{* *}$ & $0.961^{* *}$ & $0.889^{* *}$ & 0.232 & $0.965^{* *}$ & $0.943^{* *}$ \\
& $\mathrm{Fe}$ & $0.977^{* *}$ & $0.800^{* *}$ & $0.943^{* *}$ & $0.884^{* *}$ & 0.296 & $0.968^{* *}$ & $0.956^{* *}$ \\
& $\mathrm{Mn}$ & $0.978^{* *}$ & $0.850^{* *}$ & $0.983^{* *}$ & $0.944^{* *}$ & 0.392 & $0.993^{* *}$ & $0.974^{* *}$ \\
\hline $5 \mathrm{~d}$ & $\mathrm{Al}$ & $0.980^{* *}$ & $0.524^{*}$ & $0.967^{* *}$ & $0.732^{* *}$ & 0.248 & $0.962^{* *}$ & $0.923^{* *}$ \\
& $\mathrm{Fe}$ & $0.978^{* *}$ & $0.556^{* *}$ & $0.947^{* *}$ & $0.767^{* *}$ & 0.292 & $0.963^{* *}$ & $0.942^{* *}$ \\
& $\mathrm{Mn}$ & $0.989^{* *}$ & $0.619^{* *}$ & $0.970^{* *}$ & $0.865^{* *}$ & 0.418 & $0.991^{* *}$ & $0.971^{* *}$ \\
\hline $7 \mathrm{~d}$ & $\mathrm{Al}$ & $0.658^{* *}$ & -0.109 & $0.565^{* *}$ & 0.093 & -0.065 & $0.637^{* *}$ & $0.586^{* *}$ \\
& $\mathrm{Fe}$ & $0.925^{* *}$ & 0.249 & $0.890^{* *}$ & $0.643^{* *}$ & 0.366 & $0.934^{* *}$ & $0.923^{* *}$ \\
& $\mathrm{Mn}$ & $0.944^{* *}$ & 0.340 & $0.950^{* *}$ & $0.829^{* *}$ & 0.393 & $0.943^{* *}$ & $0.962^{* *}$ \\
\hline \multirow{2}{*}{$15 \mathrm{~d}$} & $\mathrm{Al}$ & $0.790^{* *}$ & -0.270 & $0.864^{* *}$ & 0.322 & 0.077 & $0.852^{* *}$ & $0.808^{* *}$ \\
& $\mathrm{Fe}$ & $0.909^{* *}$ & -0.097 & $0.889^{* *}$ & 0.257 & 0.400 & $0.934^{* *}$ & $0.863^{* *}$ \\
& $\mathrm{Mn}$ & $0.838^{* *}$ & 0.216 & $0.894^{* *}$ & 0.116 & 0.414 & $0.636^{* *}$ & $0.970^{* *}$ \\
\hline
\end{tabular}

Similar to As, the solution-borne $\mathrm{Cr}$ had a close relationship with solution-borne $\mathrm{Al}, \mathrm{Fe}$, and $\mathrm{Mn}$ on any of the five sampling occasions. The correlation coefficient tended to be relatively smaller on and after the 7th day than before and on the 5th day (Table 6).

There was a general trend that the correlation coefficient between solution-borne $\mathrm{Cu}$ and solution-borne $\mathrm{Al}, \mathrm{Fe}$, and $\mathrm{Mn}$ decreased over time during the period of the experiment. The relationship was significant at $p<0.01$ except for the sampling occasion on the 15th day and on the 7th day for $\mathrm{Al}$ (Table 6).

There was no significant relationship $(p>0.05)$ between the solution-borne $\mathrm{Pb}$ and any of the solution-borne $\mathrm{Al}, \mathrm{Fe}$, and $\mathrm{Mn}$ on any sampling occasions though the solution-borne $\mathrm{Mn}$ tended to have a larger correlation coefficient with the solution-borne $\mathrm{Pb}$, as compared to the solution-borne $\mathrm{Al}$ and Fe (Table 6).

Both $\mathrm{Zn}$ and $\mathrm{Ni}$ in the solutions were closely related to any of the solution-borne $\mathrm{Fe}, \mathrm{Mn}$, and $\mathrm{Al}$ on any sampling occasions (significant at $p<0.01$ ), although the correlation coefficient with the solution-borne $\mathrm{Al}$ was relatively smaller on the 7th day of the experiment (Table 6).

\section{Discussion}

The clear trend that the $\mathrm{pH}$ in soil solutions increased over time for all the 7 treatments suggests that proton consumption took place continuously during the period of the 15-day incubation experiment after mixing the soil with either the single or combined LMWOA solutions. This was accompanied by the enhancement of reducing conditions over time, as indicated by the consistent trend that the solution Eh decreased with increasing duration of the experiment. The temporal variation in both solution $\mathrm{pH}$ and Eh appeared to markedly complicate the mobilization-immobilization of various soil constituents, resulting in irregular variation in the EC value. Different organic acids or combinations of organic acids had differential effects on these chemical processes. However, as a whole, the EC value tended to decrease over time, and at the end of the experiment (the 15th day), EC dropped to a very low value for all the treatments. This suggests that, at this point, hydrolytic polymerization of metal complexes dominated as a result of rising $\mathrm{pH}[27,28]$. For the single organic acid treatments (T1-T3), no removal of $\mathrm{Fe}, \mathrm{Mn}$, and $\mathrm{Al}$ from the solutions took place at this point because their concentrations remained high in the solutions. However, for the combined organic acid systems, removal of these metals from the solutions occurred, as evidenced by the facts that their 
concentrations tended to decrease after either 5 or 7 days of the experiments. This suggests that the presence of multiple organic acid ligands enhanced the precipitation of solution-borne $\mathrm{Fe}, \mathrm{Mn}$, and $\mathrm{Al}$.

The lower initial pH for oxalic acid treatment can be attributed to the greater acid dissociation constant (Ka) or lower $\mathrm{pKa}$, as compared to the other two individual acid treatments (Equations (1)-(7)) [29].

$$
\begin{gathered}
\mathrm{H}_{2} \mathrm{~A}_{\mathrm{ox}} \rightleftharpoons \mathrm{HA}_{\mathrm{ox}}{ }^{-}+\mathrm{H}^{+}(\mathrm{pKa}=1.27) \\
\mathrm{HA}_{\mathrm{ox}}{ }^{-} \rightleftharpoons \mathrm{A}_{\mathrm{ox}}{ }^{2-}+\mathrm{H}^{+}(\mathrm{pKa}=4.67) \\
\mathrm{H}_{3} \mathrm{~A}_{\mathrm{cit}} \rightleftharpoons \mathrm{H}_{2} \mathrm{~A}_{\mathrm{cit}}{ }^{-}+\mathrm{H}^{+}(\mathrm{pKa}=3.13) \\
\mathrm{H}_{2} \mathrm{~A}_{\mathrm{cit}}{ }^{-} \rightleftharpoons \mathrm{HA}_{\mathrm{cit}}{ }^{2-}+\mathrm{H}^{+}(\mathrm{pKa}=4.76) \\
\mathrm{HA}_{\mathrm{cit}}{ }^{2-} \rightleftharpoons \mathrm{A}_{\mathrm{cit}}{ }^{3-}+\mathrm{H}^{+}(\mathrm{pKa}=4.67) \\
\mathrm{H}_{2} \mathrm{~A}_{\mathrm{mal}} \rightleftharpoons \mathrm{HA}_{\mathrm{mal}}{ }^{-}+\mathrm{H}^{+}(\mathrm{pKa}=1.92) \\
\mathrm{HA}_{\mathrm{mal}}{ }^{-} \rightleftharpoons \mathrm{A}_{\mathrm{mal}}{ }^{2-}+\mathrm{H}^{+}(\mathrm{pKa}=6.27)
\end{gathered}
$$

The sharp increase in $\mathrm{pH}$ during the first 3 days for the oxalic acid treatment indicates rapid consumption of $\mathrm{H}^{+}$generated from dissociation of oxalic acid (Equations (1) and (2)). This could involve protonation of variably charged organic and inorganic soil colloids (including oxides of Fe, Mn, and $\mathrm{Al}$ ) and reactions with carbonate and silicate minerals [30,31]. The slight decrease in solution-borne $\mathrm{Fe}, \mathrm{Mn}$, and $\mathrm{Al}$ prior to the 5th day of experiment suggests that release of soil-borne $\mathrm{Fe}, \mathrm{Mn}$, and $\mathrm{Al}$ to the solutions was inhibited.

The reaction between the soil-borne Fe/Mn/ $\mathrm{Al}$ oxides/hydroxides and individual organic acids could lead to the release of these metals into the solution, as illustrated in the following example for the reaction of aluminium hydroxide with citric acid:

$$
\begin{gathered}
\mathrm{nAl}(\mathrm{OH})_{3(\mathrm{~s})}+3 \mathrm{H}^{+}{ }_{(\mathrm{aq})}+\mathrm{C}_{6} \mathrm{H}_{5} \mathrm{O}_{7}{ }^{3-}{ }_{(\mathrm{aq})} \rightarrow(\mathrm{n}-1) \mathrm{Al}(\mathrm{OH})_{3(\mathrm{~s})}+\mathrm{AlC}_{6} \mathrm{H}_{5} \mathrm{O}_{7(\mathrm{~s})}+3 \mathrm{H}_{2} \mathrm{O} \\
\mathrm{AlC}_{6} \mathrm{H}_{5} \mathrm{O}_{7(\mathrm{~s})}+\mathrm{C}_{6} \mathrm{H}_{5} \mathrm{O}_{7}{ }^{3-}{ }_{(\mathrm{aq})} \rightarrow \mathrm{Al}\left(\mathrm{C}_{6} \mathrm{H}_{5} \mathrm{O}_{7}\right)_{2}{ }^{3-}{ }_{(\mathrm{aq})}
\end{gathered}
$$

In Equation (8), the attack of aluminium hydroxide by citric acid results in the formation of insoluble aluminium citrate, which further reacts with another citrate ion to form soluble aluminium citrate complex (Equation (9)). Therefore, Equation (9) represents the rate-limiting step for the organic acid-driven dissolution of aluminium hydroxide. At least before the 7th day of the experiment, the reaction equilibrium was not reached because the concentration of dissolved Al kept increasing from the 7th day to the 15th of the experiment. The malic acid treatment showed a similar trend to the citric acid, suggesting that both citric acid and malic acid behaved similarly in terms of solubilizing the $\mathrm{Al}$ in the investigated soil. The delayed release of $\mathrm{Al}$ in the oxalic acid treatment could be attributed to the smaller acid dissociation constant (Ka), as compared to the other two organic acids [27].

The close correlation among the solution-borne $\mathrm{Fe}, \mathrm{Mn}$, and $\mathrm{Al}$ suggests that these metals were solubilized consistently from the oxides of these metals upon contacts with the organic acids. The reduced correlation coefficient during the later stage of the experiment may reflect differential rate of precipitation for these metals. By comparison, the amount of three metals mobilized during LMWOA extraction was in the following decreasing order: $\mathrm{Al}>\mathrm{Fe}>\mathrm{Mn}$. This was consistent with the total concentration of these three metals contained in the investigated soil (Table 1), suggesting the strong control of the soil-borne metals on the solution-borne metals. However, when considering the ratio of solution-borne metal to soil-borne metal $\left(\mathrm{M}_{\text {solution }}: \mathrm{M}_{\text {soil }}\right)$, it is clear that $\mathrm{Mn}$ had much stronger affinity to the LMWOAs, as compared to either $\mathrm{Al}$ or Fe; $\mathrm{M}_{\text {solution }}: \mathrm{M}_{\text {soil }}$ was more than 0.23 for $\mathrm{Mn}$ while $\mathrm{M}_{\text {solution }}: \mathrm{M}_{\text {soil }}$ for either $\mathrm{Al}$ or Fe was only 0.07 .

The fact that solution-borne $\mathrm{Pb}$ was not related to any of the solution-borne $\mathrm{Fe}, \mathrm{Mn}$, and $\mathrm{Fe}$ suggests that $\mathrm{Pb}$ was not predominantly bound to the oxides of these metals. This is not in agreement 
with many other findings that show $\mathrm{Pb}$ is favourably bound to oxides of iron and manganese [32-36]. Previous investigation suggested that $\mathrm{Pb}$ in contaminated soils at this site was mainly in the form of lead sulfate [37]. Consequently, the mobilization of $\mathrm{Pb}$ was not related to the dissolution of $\mathrm{Fe}, \mathrm{Mn}$, and $\mathrm{Al}$ oxides. In contrast, $\mathrm{As}, \mathrm{Cr}, \mathrm{Zn}$, and $\mathrm{Ni}$ showed a close correlation with $\mathrm{Fe}, \mathrm{Mn}$, or $\mathrm{Al}$, suggesting the LMWOA-driven dissolution of $\mathrm{Fe}, \mathrm{Mn}$, or $\mathrm{Al}$ had a major control on the mobilization of these elements of potential toxicity. It is interesting to note that the correlation coefficient for $\mathrm{Cu} v \mathrm{vs}$. $\mathrm{Fe} / \mathrm{Mn} / \mathrm{Al}$ and $\mathrm{Cd}$ vs. $\mathrm{Fe} / \mathrm{Mn} / \mathrm{Al}$ varied over time. During the earlier stage of the experiment, a close correlation was observed, suggesting that the solution-borne $\mathrm{Cu}$ and $\mathrm{Cd}$ were essentially of $\mathrm{Fe} / \mathrm{Mn} / \mathrm{Al}$ oxide sources. In particular, it is likely that $\mathrm{Cd}$ was mainly bound to $\mathrm{Mn}$ oxides given the closer correlation between these two metals. The poor correlation between $\mathrm{Cd}$ or $\mathrm{Cu}$ and $\mathrm{Fe} / \mathrm{Mn} / \mathrm{Al}$ during the later stage of the experiment may be attributed to different immobilization rate between $\mathrm{Cd} / \mathrm{Cu}$ and $\mathrm{Fe} / \mathrm{Mn} / \mathrm{Al}$.

\section{Conclusions}

Although the capacity of malic acid to mobilize $\mathrm{Fe}, \mathrm{Mn}$, and $\mathrm{Al}$ in the contaminated soil was weaker compared to citric and oxalic acids, there was a general trend showing that the concentration of dissolved $\mathrm{Fe}, \mathrm{Mn}$, and $\mathrm{Al}$ increased over time during the 15-day experiment with marked increase in metal concentrations only occurring after 5 or 7 days of the experiment. For the same LMWOA treatment, the three metals showed a very similar temporal variation pattern. The total amount of $\mathrm{Fe}$, $\mathrm{Mn}$, and $\mathrm{Al}$ contained in the soil had an important control on the concentration of the dissolved $\mathrm{Fe}$, $\mathrm{Mn}$, and $\mathrm{Al}$, respectively. Manganese oxides appeared to be more prone to LMWOA attack. However, in the presence of multiple LMWOAs, the soil-borne $\mathrm{Fe}, \mathrm{Mn}$, and $\mathrm{Al}$ were mobilized rapidly within the first 5 or 7 days of the experiment and then tended to decrease. The co-existence of multiple LMWOAs appeared to enhance the formation of insoluble $\mathrm{Fe}, \mathrm{Mn}$, and $\mathrm{Al}$ organic complexes, leading to their precipitation. The LMWOA-driven dissolution of $\mathrm{Fe}, \mathrm{Mn}$, or $\mathrm{Al}$ had a major control on the mobilization of $\mathrm{As}, \mathrm{Cr}, \mathrm{Zn}, \mathrm{Ni}, \mathrm{Cu}$, and $\mathrm{Cd}$, but not $\mathrm{Pb}$, which was not largely derived from oxides of iron, manganese, and aluminium in the investigated soil.

Author Contributions: Conceptualization, C.L. and J.Q.; Methodology, J.Q.; Validation, C.L., J.Q. and O.E.; Investigation, J.Q. and O.E.; Data Curation, J.Q.; Writing-Original Draft Preparation, C.L.; Writing-Review \& Editing, J.Q.; Visualization, J.Q.; Supervision, C.L.

Funding: This research received no external funding

Conflicts of Interest: The authors declare no conflict of interest.

\section{References}

1. Lee, G.; Bigham, J.M.; Faure, G. Removal of trace metals by coprecipitation with Fe, $\mathrm{Al}$ and Mn from natural waters contaminated with acid mine drainage in the Ducktown Mining District, Tennessee. Appl. Geochem. 2002, 17, 569-581. [CrossRef]

2. Suda, A.; Makino, T. Functional effects of manganese and iron oxides on the dynamics of trace elements in soils with a special focus on arsenic and cadmium: A review. Geoderma 2016, 270, 68-75. [CrossRef]

3. Violante, A.; Ricciardella, M.; Pigna, M. Adsorption of heavy metals on mixed Fe-Al oxides in the absence or presence of organic ligands. Water Air Soil Pollut. 2003, 145, 289-306. [CrossRef]

4. Hartley, W.; Edwards, R.; Lepp, N.W. Arsenic and heavy metal mobility in iron oxide-amended contaminated soils as evaluated by short-and long-term leaching tests. Environ. Pollut. 2004, 131, 495-504. [CrossRef] [PubMed]

5. Feng, X.H.; Zhai, L.M.; Tan, W.F.; Liu, F.; He, J.Z. Adsorption and redox reactions of heavy metals on synthesized Mn oxide minerals. Environ. Pollut. 2007, 147, 366-373. [CrossRef]

6. Bolan, N.; Kunhikrishnan, A.; Thangarajan, R.; Kumpiene, J.; Park, J.; Makino, T.; Kirkham, M.B.; Scheckel, K. Remediation of heavy metal (loid) s contaminated soils-to mobilize or to immobilize? J. Hazard. Mater. 2014, 266, 141-166. [CrossRef] 
7. Violante, A.; Ricciardella, M.; Pigna, M.; Capasso, R. Effects of organic ligands on the sorption of trace elements onto metal oxides and organo-mineral complexes. In Biogeochemistry of Trace Elements in the Rhizosphere; Huang, P.M., Gobran, G.R., Eds.; Elsevier B.V.: Amsterdam, The Netherlands, 2005; pp. 157-182.

8. Cook, F.J.; Hicks, W.; Gardner, E.A.; Carlin, G.D.; Froggatt, D.W. Export of acidity in drainage water from acid sulphate soils. Mar. Pollut. Bull. 2000, 41, 319-326. [CrossRef]

9. Mosley, L.M.; Shand, S.; Self, P.; Fitzpatrick, R. The geochemistry during management of lake acidification caused by the rewetting of sulfuric $(\mathrm{pH}<4)$ acid sulfate soils. Appl. Geochem. 2014, 41, 49-61.

10. Sukitprapanon, T.; Suddhiprakarn, A.; Kheoruenromne, I. Partitioning and potential mobilization of aluminum, arsenic, iron, and heavy metals in tropical active and post-active acid sulfate soils: Influence of long-term paddy rice cultivation. Chemosphere 2018, 197, 691-702. [CrossRef]

11. Davies, S.H.R.; Morgan, J.J. Manganese (II) oxidation-kinetics on metal-oxide surfaces. J. Colloid Interface Sci. 1989, 129, 63-77. [CrossRef]

12. Burton, E.D.; Bush, R.T.; Sullivan, L.A.; Mitchell, D.R.G. Schwertmannite transformation to goethite via the Fe(II) pathway: Reaction rates and implications for iron-sulfide formation. Geochim. Cosmochim. Acta 2008, 72, 4551-4564. [CrossRef]

13. Kuan, W.H.; Wang, M.K.; Huang, P.M.; Wu, C.W.; Chang, C.M.; Wang, S.L. Effect of citric acid on aluminum hydrolytic speciation. Water Res. 2005, 39, 3457-3466. [CrossRef] [PubMed]

14. Mimmo, T.; Del Buono, D.; Terzano, R.; Tomasi, N.; Vigani, G. Rhizospheric organic compounds in the soil-microorganism-plant system: Their role in iron availability. Eur. J. Soil Sci. 2014, 65, 629-642. [CrossRef]

15. Clarholm, M.; Skyllberg, U.; Roslin, A. Organic acid induced release of nutrients from metal-stabilized soil organic matter-the unbutton model. Soil Biol. Biochem. 2015, 84, 168-176. [CrossRef]

16. Dotaniya, M.L.; Meena, V.D. Rhizosphere effect on nutrient availability in soil and its uptake by plants: A review. Proc. Natl. Acad. Sci. India Sect. B Biol. Sci. 2015, 85, 1-12. [CrossRef]

17. Perez-Benito, J.; Arias, F.C.; Amat, E. A kinetic study of the reduction of colloidal manganese dioxide by oxalic acid. J. Colloid Interface Sci. 1996, 177, 288-297. [CrossRef]

18. Saad, E.M.; Sun, J.; Chen, S.; Borkiewicz, O.J.; Zhu, M.Q.; Duckworth, O.W.; Tang, Y.Z. Siderophore and organic acid promoted dissolution and transformation of $\mathrm{Cr}$ (III)-Fe (III)-(oxy) hydroxides. Environ. Sci. Technol. 2017, 51, 3223-3232. [CrossRef]

19. Novo, L.A.B.; Castro, P.M.L.; Alvarenga, P.; da Silva, E.F. Plant growth-promoting rhizobacteria-assisted phytoremediation of mine soils. In Bio-Geotechnologies for Mine Site Rehabilitation; Elsevier: Amsterdam, The Netherlands, 2018; Volume 1, pp. 281-295.

20. Lee, S.O.; Tran, T.; Jung, B.H.; Kim, S.J.; Kim, M.J. Dissolution of iron oxide using oxalic acid. Hydrometallurgy 2007, 87, 91-99. [CrossRef]

21. Lee, J.C.; Kim, E.J.; Kim, H.W.; Baek, K. Oxalate-based remediation of arsenic bound to amorphous Fe and Al hydrous oxides in soil. Geoderma 2016, 270, 76-82. [CrossRef]

22. Gu, B.H.; Schmitt, J.; Chen, Z.H.; Liang, L.Y.; McCarthy, J.F. Adsorption and desorption of natural organic matter on iron oxide: mechanisms and models. Environ. Sci. Technol. 1994, 28, 38-48. [CrossRef]

23. Rengel, Z. Availability of Mn, Zn and Fe in the rhizosphere. J. Soil Sci. Plant Nutr. 2015, 15, 397-409. [CrossRef]

24. Mukwaturi, M.; Lin, C.X. Mobilization of heavy metals from urban contaminated soils under water inundation conditions. J. Hazard. Mater. 2015, 285, 445-452. [CrossRef] [PubMed]

25. Euro. Council Directive of 12 June 1986 on the protection of the environment, and in particular of the soil, when sewage sludge is used in agriculture (86/278/EEC). Off. J. Eur. Commun. 1986, 181, 6-12.

26. Jeffries, J. CLEA Software (Version 1.05) Handbook; Environment Agency: Bristol, UK, 2009.

27. Spiro, T.G.; Pape, L.; Saltman, P. Hydrolytic polymerization of ferric citrate. I. Chemistry of the polymer. J. Am. Chem. Soc. 1967, 89, 5555-5559. [CrossRef]

28. Chang, C.A.; Wu, B.H.; Kuan, B.Y. Macrocyclic lanthanide complexes as artificial nucleases and ribonucleases: Effects of $\mathrm{pH}$, metal ionic radii, number of coordinated water molecules, charge, and concentrations of the metal complexes. Inorg. Chem. 2005, 44, 6646-6654. [CrossRef]

29. Goldberg, R.; Kishore, N.; Lennen, R. Thermodynamic Quantities for the Ionization Reactions of Buffers. J. Phys. Chem. Ref. Data 2002, 31, 231-370. [CrossRef]

30. Swift, R.S.; McLaren, R.G. Micronutrient adsorption by soils and soil colloids. In Interactions at the Soil Colloid-Soil Solution Interface; Springer: Dordrecht, The Netherlands, 1991; pp. 257-292. 
31. Hill, D.M.; Aplin, A.C. Role of colloids and fine particles in the transport of metals in rivers draining carbonate and silicate terrains. Limnol. Oceanogr. 2001, 46, 331-344. [CrossRef]

32. Lofts, S.; Tipping, E. Solid-solution metal partitioning in the Humber rivers: Application of WHAM and SCAMP. Sci. Total Environ. 2000, 251-252, 381-399. [CrossRef]

33. Weng, L.P.; Temminghoff, E.J.M.; van Riemsdijk, W.H. Contribution of individual sorbents to the control of heavy metal activity in sandy soil. Environ. Sci. Technol. 2001, 32, 4436-4443. [CrossRef]

34. Ash, C.; Tejnecký, V.; Šebek, O.; Houška, J.; Chala, A.T.; Drahota, P.; Drábeka, O. Redistribution of cadmium and lead fractions in contaminated soil samples due to experimental leaching. Geoderma 2015, 241-242, 126-135. [CrossRef]

35. Gunawardana, C.; Egodawatta, P.; Goonetilleke, A. Adsorption and mobility of metals in build-up on road surfaces. Chemosphere 2015, 119, 1391-1398. [CrossRef] [PubMed]

36. Tiberg, C.; Sjöstedt, C.; Gustafsson, J.P. Metal sorption to Spodosol Bs horizons: Organic matter complexes predominate. Chemosphere 2018, 196, 556-565. [CrossRef] [PubMed]

37. Onireti, O.O.; Lin, C.X.; Qin, J.H. Combined effects of low-molecular-weight organic acids on mobilization of arsenic and lead from multi-contaminated soils. Chemosphere 2017, 170, 161-168. [CrossRef] [PubMed]

(C) 2018 by the authors. Licensee MDPI, Basel, Switzerland. This article is an open access article distributed under the terms and conditions of the Creative Commons Attribution (CC BY) license (http:/ / creativecommons.org/licenses/by/4.0/). 